\title{
OS DADOS GENÉTICOS E O DIREITO À PRIVACIDADE: a declaração universal sobre o genoma humano e os direitos humanos
}

\author{
Gisele Echterhoff*
}

\begin{abstract}
RESUMO
O direito à privacidade dos dados genéticos é um trabalho que tem como escopo analisar algumas transformações da sociedade no campo das ciências biomédicas, demonstrando que Direito deve agir como uma ferramenta eficaz para regulamentar as inovações biotecnológicas relacionadas à engenharia genética e ao projeto genoma humano. Logo, o presente trabalho demonstrará a necessária proteção dos novos direitos inerentes à biotecnologia, dentre eles o direito à privacidade dos dados genéticos. Destarte se examinará os direitos da personalidade, demonstrando que esta categoria é fruto de uma mudança de paradigmas do direito contemporâneo com o reconhecimento da pessoa como o núcleo do ordenamento jurídico. Sob este enfoque se realizará um exame comparativo entre o direito à privacidade e os dados genéticos, apontando os malefícios decorrentes do acesso indiscriminado às informações genéticas e da sua utilização com intuito eugênico. Finalmente se demonstrará a imprescindibilidade de compatibilização entre o direito à privacidade, os valores éticojurídicos sintetizados pelo princípio da dignidade da pessoa humana e os avanços decorrentes da engenharia genética, examinando, ao final, a Declaração Universal sobre o Genoma Humano e os Direitos Humanos.

Palavras-chave: Revolução Genética. Projeto Genoma Humano. Dados genéticos. Direitos da personalidade. Direito à privacidade.

Sumário: 1 INTRODUÇÃO; 2 A BIOTECNOLOGIA E OS OUTROS RAMOS; 3 OS DIREITOS DA PERSONALIDADE; 4 DADOS GENÉTICOS VERSUS DIREITO À PRIVACIDADE: A DECLARAÇÃO UNIVERSAL SOBRE O GENOMA HUMANO E DIREITOS HUMANOS; 5 CONSIDERAÇÕES FINAIS; 6 REFERÊNCIAS.
\end{abstract}

* Mestranda em Direito Econômico e Social - PUCPR. Endereço eletrônico: gisae@ig.com.br. 


\section{INTRODUÇÃO}

O progresso técnico-científico, em especial na área médico-biológica, tem trazido perplexidades para a humanidade com recentes descobertas envolvendo o mapeamento genético, terapia genética, clonagem humana, modernas técnicas de procriação artificial, entre tantas outras "novidades" que tanto proporcionam o progresso quanto o medo.

Tais avanços tecnológicos, nas denominadas ciências biomédicas, trazem a tona diversas indagações jurídico-morais, visando a se estabelecer os limites da compatibilização entre os valores ético-jurídicos e o progresso da biotecnologia.

Portanto, o que fazer? Quem cabe agir? Quais são os limites para a tão amada e temida revolução? Várias são as perguntas que clamam por respostas imediatas para evitar que tal revolução proporcione, além do progresso desejado, problemas inesperados para a sociedade atual e para as futuras gerações (alterações no patrimônio genético que as afetem de forma imprevisível).

As indagações se agigantam ainda mais quando se analisa a questão dos direitos à privacidade em face destes avanços tecnológicos, da possibilidade de acesso a informações genéticas, bem como das diversas e perversas possibilidades de utilização de tais informações com o intuito discriminatório e eugênico. Portanto, torna-se imprescindível analisar, sendo este o objetivo do presente trabalho, a polêmica relacionada ao direito à privacidade em face dos dados genéticos.

Iniciar-se-á o estudo por um exame, mesmo que superficial, das inovações tecnológicas no âmbito das ciências médico-biológicas, do conceito de biotecnologia, de bioética, do Biodireito e de Engenharia Genética, englobando ainda o Projeto Genoma Humano e suas implicações para a humanidade.

O outro ponto a ser analisado é relacionado aos Direitos da Personalidade, estudando um pouco mais detidamente o direito à privacidade para ao final relacionálo a questão dos dados genéticos, finalizando com a análise da Declaração Universal sobre o Genoma Humano e os Direitos Humanos e a proteção por ela conferida ao 
direito à privacidade dos dados genéticos.

\section{A BIOTECNOLOGIA E OS OUTROS RAMOS}

\subsection{A BIOTECNOLOGIA, A BIOÉTICA E O BIODIREITO}

Sabe-se que o grande impulso desenvolvimentista da biotecnologia ocorreu em especial no final da década de 80 e durante os anos 90, fundado primordialmente no incrível desenvolvimento tecnológico desta época. Porém, não se pode negar que já no início da década de 70 a humanidade assistiu ao início desta revolução biotecnológica, com a combinação genética e a recombinação do DNA o que possibilitou a aplicação de conhecimentos cumulativos.

Foi também na década de 70, em especial em 1973, que Stanley Cohen, da Universidade de Stanford e Herbert Boyer da Universidade da Califórnia, em São Francisco, descobriram o método de clonagem genética, bem como em 1975, pesquisadores de Harvard isolaram o primeiro gene de mamíferos, a partir da hemoglobina de um coelho, e, em 1977, o primeiro gene humano foi clonado.

A partir destes conhecimentos a evolução no âmbito da biotecnologia já é uma realidade, sendo que se pode dizer que a humanidade, cada vez mais, está sendo alarmada por possibilidades nunca antes pensadas, as quais têm como finalidade a busca dos "segredos da vida" através de modernas técnicas das biociências.

Ana Paula Myszczuk ${ }^{1}$, citando Frijop Capra, analisa a inter-relação entre a Biotecnologia e a Engenharia Genética afirmando que:

1 MYSCZUK, Ana Paula. Limites jurídicos à manipulação do genoma humano: a Declaração Universal do Genoma Humano e dos Direitos Humanos, a Constituição Federal de 1988 e atual Legislação Brasileira de Biossegurança. Curitiba, 2002, p. 15-16. Dissertação de Mestrado Departamento de Direito, Pontifícia Universidade Católica do Paraná. 
quando pensamos nas tecnologias avançadas do século XXI, nossa mente se volta não só para a informática, mas também para a biotecnologia. Como a Revolução da Informática, a 'Revolução Biotecnológica' começa nos anos 1970 com diversas inovações decisivas e alcançou seu clímax inicial na década de 1990'. Esta 'revolução' só se concretizou em virtude do aprofundamento de conhecimentos da Bioquímica, Biologia Molecular, Microbiologia, Engenharia Bioquímica e Engenharia Genética.

Portanto, a Biotecnologia é o "conjunto de técnicas e processos biológicos que possibilitam a utilização da matéria viva para degradar, sintetizar e produzir outros materiais. Engloba a elaboração das próprias técnicas, processos e ferramentas as espécies, via seleção natural." ${ }^{2}$

Já quando se fala em Bioética se constata que é um ramo do conhecimento que tem a sua origem recentemente, há aproximadamente meio século, ${ }^{3}$ sendo que se pode considerá-la como fruto de nossa época, de nossa civilização tecnocientífica.

Ressalta-se que, conforme o jusfilósofo Vicente de Paulo Barreto, ${ }^{4}$ alguns de seus temas centrais - a saúde, a vida e a morte - já foram objeto de pesquisa nas origens da reflexão filosófica e da medicina na cultura do Ocidente. Desde os primórdios de nossa civilização o homem se vê defrontado com situações que merecem decisões morais, o que não poderia ser diferente no ramo das ciências médicas e biológicas.

A reflexão filosófica em torno da moral e da ética já foi tema de preocupação de renomados filósofos ${ }^{5}$ que elaboraram ou tentaram elaborar teorias da moral,

${ }^{2}$ PESSINI, Léo; BARCHIFONTAINE, Christian de Paul de. Problemas atuais de bioética. 4. ed. rev. ampl. São Paulo: Loyola, 1997, p. 251.

${ }^{3}$ BARRETO, Vicente de Paulo. Bioética, biodireito e direitos humanos. Revista Ethica, v. 5, n. 1, 1998. Disponível em http://www.dhnet.org.br/direitos/direitosglobais/paradigmas_textos/ v_barreto.html. Acesso em: 2 dez. 2004.

${ }^{4}$ Ibid.

${ }^{5}$ Entre eles pode citar-se Sócrates, Aristóteles e em especial Immanuel Kant, sendo que conforme Joaquim Carlos Salgado "nenhuma teoria da moral, nenhuma ética até Kant procurou assentar-se em princípios a priori, por isso universais, garantidores da sua validade. E mais, todas as éticas até então existentes buscaram o fundamento da sua validade fora delas mesmas, em conceitos externos. Só a ética kantiana procura princípios próprios para a sua fundamentação. Daí a preocupação mais importante de Kant no preparo do seu edifício ético: o combate à ética empírica e à ética eudemônica através de dois elementos decisivos de sua experiência histórica": a razão e o dever. (SALGADO, Joaquim Carlos. A idéia de justiça em Kant: seu fundamento na liberdade e na igualdade. 2. ed. Belo Horizonte: UFMG, 1995, p. 144-145). 
visando modelar a conduta humana de acordo com uma moralidade preestabelecida.

No campo das ciências médicas e biológicas, conforme o jusfilósofo Vicente de Paulo Barreto, ${ }^{6}$ "a primeira formulação de um sistema normativo, no qual se reconhecia a relação necessária entre a prática da medicina, e a conseqüente busca da cura das doenças, com o respeito aos valores da pessoa humana" pode ser encontrada no juramento hipocrático, na Grécia Antiga.

Sendo assim, desde a Antigüidade, a prática médica possuía um referencial ético que acabou por ser a base dos códigos de ética profissional, o corpus da deontologia medica. Contudo, o termo "deontologia" somente veio a ser empregado em 1834, pelo filosofo inglês Jeremy Bentham, que através de seu livro Deontology or Science of Morality buscava criar uma nova área da filosofia que deveria tratar da ciência ou teoria do que é necessário ser feito, tornando ética e ciência do que é necessário ser feito sinônimas. ${ }^{7}$ No entanto, tal termo perdeu suas conotações filosóficas e passou somente a ser empregado, durante o século XIX, para significar os códigos de ética profissionais.

O termo bioética, conforme o jurista Elton Dias Xavier, ${ }^{8}$ surgiu somente na década de 70 em um trabalho do oncologista Van Rensselder Potter, da universidade americana de Wisconsin, intitulado Bioética: uma ponte para o futuro, no qual buscava "destacar a importância das ciências biológicas como garantidoras da qualidade de vida e sobrevivência do planeta". 9

Forçoso se faz ressaltar a influência da civilização tecnocientífica na

${ }^{6}$ BARRETO, op. cit., passim.

${ }^{7}$ Ibid.

${ }^{8}$ XAVIER, Elton Dias. A bioética e o conceito de pessoa: a re-significação jurídica do ser enquanto pessoa. Bioética, v. 8, n. 2, 2000. Disponível em http://www.portalmedico.org.br/revista/bio2v8/simpo2.htm. Acesso em: 15 de jan. 2005.

${ }^{9}$ (FERREIRA, Jussara Suzi Assis Borges Nasser. Bioética e biodireito. Disponível em http://www.uel.br/cesa/dir/pos/publicacoes/pubjussaraf.html. Acesso em: 20 jan. 2005.). Salienta-se a afirmação de Vicente de Paulo Barreto de que "o precursor do uso do termo empregou-o em sentido bastante diferenciado daquele que encontramos na atualidade", sendo que tinha um objetivo moralpedagógico, Observa que teria sido Andre Hellegers, fisiologista holandês quem "passou a empregar a palavra em sentido mais amplo, relacionando-a com a ética da medicina e das ciências biológicas". (BARRETO, op. cit.) 
elaboração e no desenvolvimento da bioética, cujos avanços no campo da tecnologia acabam por tornar insuficiente o paradigma ético-profissional da medicina, estabelecido na Grécia Antiga, razão pela qual o jusfilósofo Vicente de Paulo Barreto ${ }^{10}$ afirma a existência de um "vazio ético" resultante da denominada crise ética, que se refere ao conflito entre aquela tradição da ética estritamente profissional e os valores da cultura da tecno-civilização, "que servem como alicerces para a construção de novas, imprevisíveis e descontroladas relações sociais e econômicas".

Vários fatos históricos, bem como várias descobertas cientificas no campo da biotecnologia acarretaram a necessidade de uma rediscussão dos valores éticos da civilização. Dentre aqueles se pode citar as experiências de médicos nazistas em judeus nos campos de concentração, que acarretou a afirmação de Hannah Arendt ${ }^{11}$ de que o ser humano se tornou supérfluo com a banalidade do mal.

Entre as descobertas científicas se pode citar a fertilização in vitro que também foi um fato que desencadeou a discussão e evolução da Bioética, sendo que, posteriormente, surgiram e surgem ainda mais importantes questões que clamam pelo exame da Bioética: Projeto Genoma Humano, dados genéticos, clonagem, etc.

Demonstrando de forma contundente como o surgimento e o desenvolvimento da Bioética são resultantes dos desafios encontrados com os avanços tecnológicos e culturais da civilização tecnocientífica, assim se expressa Vicente de Paulo Barreto: ${ }^{12}$

O desenvolvimento das ciências e das técnicas, nos dois últimos séculos, trouxe consigo desafios que têm a ver com o surgimento de novos tipos de relações sociais no quadro cultural da tecno-civilização. O renascimento da consciência do homem contemporâneo em situar-se face ao fato de que, o paradigma científico domina cada vez mais as forcas da natureza e, ao mesmo tempo, interfere de forma crescente no mundo natural, suscitando problemas que não encontram respostas no quadro da própria cultura tecnocientífica, onde surgiram e desenvolveram-se. A principal dessas intervenções é a que ocorre no corpo das ciências biológicas, onde o homem, ao ampliar o seu domínio sobre a natureza, intervém na sua própria condição natural de pessoa e possibilita a implantação de tecnologias sem

${ }^{10}$ Ibid.

11 ARENDT, Hannah. Origens do totalitarismo. Trad. Roberto Raposo. São Paulo: Companhia das Letras, 1998.

${ }^{12}$ BARRETO, op. cit. 
previsão quanto às suas conseqüências. [...]

A bioética nasce, assim, como uma resposta a desafios encontrados no corpo de uma cultura, de um paradigma do conhecimento humano e de uma civilização. [...]

O nascimento da bioética ocorreu, assim, em contexto histórico e social específico (Parizeau, 1996), correspondendo ao momento de crise da ética médica tradicional, restrita à normatização do exercício profissional da medicina, que não conseguia responder aos desafios morais encontrados no contexto da ciência biológica contemporânea.

Sendo assim, visando conceituar Bioética, cita-se a definição apresentada pelo jusfilósofo Vicente de Paulo Barreto ${ }^{13}$ como sendo o ramo da ética filosófica que se ocupa do "estudo das condições de possibilidade dos valores, normas e princípios, que procuram ordenar o avanço científico e tecnológico". ${ }^{14}$

Contudo, a Bioética mesmo com a pretensão de encontrar soluções às questões éticas suscitadas pelos avanços no campo da biotecnologia, vê-se impotente ao constatar-se como campo da ética, que nada mais é do que a ciência do dever moral, não detém os meios coativos indispensáveis em algumas situações, o que somente pode ser concedido pelo Direito.

Neste sentido a Professora Jussara Maria Leal de Meirelles afirma que a norma moral é insuficiente porque somente opera no plano interno da consciência, sendo indispensável assim a existência e a atuação de normas jurídicas, "não somente éticas $\left[{ }^{15}\right]$, pois somente o caráter coercitivo daquelas impedirá ao científico sucumbir

\footnotetext{
${ }^{13}$ Ibid.

${ }^{14}$ Imprescindível se faz, mesmo que superficialmente, apontar os princípios da Bioética: o da autonomia ("ou do respeito às pessoas por suas próprias opiniões e escolhas, segundo valores e crenças pessoais"), o da beneficência ("que se traduz na obrigação de não causar dano e de extremar os benefícios e minimizar os riscos"), o da justiça ("ou imparcialidade na distribuição dos riscos e dos benefícios, não podendo um pessoas ser tratada de maneira distinta de outra, salvo haja entre ambas alguma diferença relevante") e o da não-maleficência ("segundo o qual não se deve causar mal a outro"). (BARBOZA, Heloisa Helena. Princípios da bioética e do biodireito. Bioética, v. 8, n. 2, p. 209-216, 2000. Disponível em: <http://www.direito.médico.vilabol.uol.com.br/heloisa.htm> Acesso em: 8 mar.2005).

${ }^{15}$ Neste ponto cumpre ressaltar que a referida jurista conclama "que o amplo leque de princípios que rege o ordenamento jurídico brasileiro tem base ética, eis que o Direito existe para o homem e o homem é valor." (MEIRELLES, Jussara Maria Leal. Bioética e biodireito. In: BARBOZA, Heloíza Helena; BARRETO, Vicente de Paulo [orgs.]. Temas de biodireito e bioética. Rio de Janeiro: Renovar, 2001. p. 88).
} 
a tentação experimentalista e à pressão de interesses econômicos". ${ }^{16}$

E conclui a autora que o objeto do Biodireito "é a fundamentação e pertinência das normas jurídicas, de maneira a adequá-las aos princípios e valores relativos à vida e à dignidade humanas trazidos pela Ética." Sendo que isso equivaleria a afirmar a "existência do Biodireito como novo ramo do conhecimento e sua adequação com a Bioética". ${ }^{17}$

\subsection{A ENGENHARIA GENÉTICA E O PROJETO GENOMA HUMANO}

Resta analisar agora, mais detidamente, o Projeto Genoma Humano, partindose da análise da Engenharia Genética, da sua importância no âmbito da biotecnologia e, principalmente, das diversas conseqüências potencialmente perigosas e que necessitam de limites éticos e jurídicos, com o fito de evitar a afronta aos valores humanistas de nossa sociedade contemporânea.

Verifica-se que "o desafio mais imediato da bioética [...] veio justamente das descobertas da engenharia genética". ${ }^{18}$ Contudo, quando se fala em engenharia genética, além de questões terminológicas, ${ }^{19}$ há ainda a questão da delimitação de tal técnica, pois muitas vezes outras intervenções sobre a vida (ex.: procriação artificial) são tidas como manipulações genéticas, quando na verdade somente se poderá considerar como engenharia genética quando no momento da procriação in vitro houver a realização de intervenções sobre o código genético do embrião e dos

${ }^{16}$ Ibid., p. 90-91.

${ }^{17}$ Ibid., p. 96.

${ }^{18}$ SGRECCIA, Elio. Manual de bioética. São Paulo: Loyola, 1996. v. 1: Fundamentos e ética biomédica , p. 213.

19 Utilização das expressões "manipulação genética" e "engenharia genética" como sinonímicas, quando a primeira expressão é "muito genérica e não pode significar outra coisa senão uma intervenção qualquer (manipular = manusear, transformar com as mãos) sobre o patrimônio genético" e a segunda, conforme se verificará, tem uma acepção mais restrita. (Ibid.). 
gametas, razão pela qual Elio Sgreccia afirma que estas duas temáticas - engenharia genética e procriação artificial - devem ser tidas como distintas. ${ }^{20}$

Dentro destas advertências, Elio Sgreccia conceitua a engenharia genética como "o conjunto das técnicas que tendem a transferir para a estrutura da célula de um ser vivente algumas informações genéticas que de outro modo não teria tido." Ressalta, entretanto, o autor que esta definição também engloba as técnicas de engenharia genética com fins de diagnóstico, pois para tal desiderato "é necessário recorrer a combinações e intervenções que fazem com que também o diagnóstico genético entre no âmbito da engenharia genética". ${ }^{21}$

Cita-se, ainda, o conceito de Karina Schuch Brunet para quem a "engenharia genética é a modificação biológica do Homem pela manipulação direta de seu DNA, através da inserção ou deleção de fragmentos específicos - genes - independente do uso terapêutico ou experimental. Não se confunde, assim, com a manipulação genética, que é uma acepção mais genérica de toda e qualquer intervenção no ser humano, não necessariamente no seu código genético". ${ }^{22}$

Pela análise superficial dos conceitos acima transcritos se vislumbra os diversos aspectos problemáticos da utilização destas técnicas, entre as quais se pode citar as alterações significativas e sem previsão ainda das suas conseqüências no código genético de animais, plantas e, principalmente, em seres humanos; a possibilidade de eugenia; a utilização dos dados genéticos dos seres humanos com fins ilícitos e discriminatórios ferindo frontalmente o direito à privacidade e tantos outros direitos fundamentais (ex.: fins trabalhistas, contratuais - seguradoras, planos de saúde - o diagnóstico genético pré-natal e a indução ao aborto, etc.).

Quando se fala em dados genéticos e diagnósticos de doenças através da pesquisa destes dados, impossível se faz que se olvide de examinar o Projeto Genoma Humano.

\footnotetext{
${ }^{20}$ Ibid.

${ }^{21}$ Ibid., p. 213-214.

${ }^{22}$ BRUNET, Karina Schuch. Engenharia genética: implicações éticas e jurídicas. Revista
} 
Veja-se, o genoma é o conjunto dos genes que se encontra em cada célula do ser vivo, sendo que os genes controlam o desenvolvimento embrionário e a formação de um ser humano, portanto, é no genoma humano que as informações genéticas estão armazenadas.

Portanto, constata-se que o conhecimento e a compreensão dos genes humanos tornaram-se questões de primordial atenção pelos cientistas do mundo todo no decorrer do desenvolvimento das ciências biomédicas, principalmente quando se verifica que seria indispensável tal conhecimento no tratamento de doenças que direta ou indiretamente estão relacionadas com alterações genéticas.

Sendo assim, buscando identificar todos os genes humanos, bem como as suas funções é que em meados da década de 80 alguns pesquisadores já iniciaram estudos neste âmbito, sendo que em 1986 "é mencionada pela primeira vez, publicamente, a idéia de se seqüenciar todo o genoma." 23

Ressalta-se que as primeiras manifestações ligadas ao seqüenciamento do genoma humano são tomadas nos EUA, sendo que o Departamento de Energia (DOE) e a National Institutes of Health (NIH) é que criaram o Projeto Genoma Humano, o qual foi formalmente iniciado em meados de 1990 e finalizado em 26 de junho de 2000, com a publicação dos dados obtidos (o qual contou também com o apoio internacional através de agências análogas as americanas que coordenaram esses estudos em outros paises, como Inglaterra, Franca, Itália, Canadá, Japão e Brasil). ${ }^{24}$

Ressalta-se que várias são as questões éticas, jurídicas e sociais que se relacionam as conseqüências do mapeamento do genoma humano, sendo que, sem dúvida, também existem diversas conseqüências favoráveis, como a possibilidade de, conhecendo diretamente os mecanismos de certas doenças, desenvolverem-se os meios

Jurídica, São Paulo, n. 274, p. 44, 2000.

${ }^{23}$ PASSOS-BUENO, Maria Rita. O projeto genoma humano. Bioética, Brasília, v. 5, n. 2, p. 145-146, 1997.

${ }^{24}$ Para uma análise mais aprofundada de todo o aspecto histórico do desenvolvimento do Projeto Genoma Humano ver, entre tantos outros autores, Ana Paula Mysczuk (MYSCZUK, op.cit., p. 22-27) e Maria Rita Passos-Bueno (PASSOS-BUENO, op.cit., p. 145-146). 
necessários para o seu tratamento. ${ }^{25}$

Dentre os problemas possíveis se pode citar: privacidade das informações genéticas, segurança e eficácia da Medicina Genética e justiça no uso das informações genéticas. $^{26}$

Neste sentido, Sergio D. J. Pena afirma que três são os elementos preponderantes no âmbito destas questões: "a comunidade cientifica do PGH que vai gerar o novo conhecimento, indiferente ou não a seus aspectos éticos; a comunidade empresarial, que vai transformar este conhecimento em produtos e oferecê-lo à população; e finalmente a sociedade como um todo, que vai absorver e incorporar o novo conhecimento em sua visão do mundo e suas praticas sociais, além de consumir os novos produtos". ${ }^{27}$

Sem adentrar mais detidamente nesta análise, mas levando em conta que as considerações já feitas demonstram a problemática do tema proposto, bem como a inter-relação entre as conseqüências da Engenharia Genética e o direito à privacidade, necessário se faz iniciar o exame dos direitos da personalidade e, em especial, do direito à privacidade.

${ }^{25}$ Entre os benefícios do Projeto Genoma Humano Elio Sgreccia cita: a possibilidade de identificar os genes responsáveis pelas doenças hereditárias e de poder proceder sucessivamente à geneterapia; a realização de um arquivo internacional de todas as bases azotadas que compõem e representam o genoma humano; a caracterização de alguns tipos, mediante o emprego de polimorfismos de DNA, em geral para uso criminológico ou de pesquisa de paternidade ou, ainda, para conhecer as predisposições à doença num determinado ambiente de trabalho. Ressalta-se que o autor também expressamente levanta os problemas diretamente relacionados a estes benefícios, apontando até que ponto tais utilizações são aceitáveis, como, por exemplo, ressalta que no âmbito das relações trabalhistas a pesquisa genética deve ter como objetivo a avaliação dos riscos em relação à saúde do trabalhador, ou seja, deve visar prevenir uma patologia, sendo inaceitável que estas pesquisas busquem a seleção tendente a excluir os trabalhadores geneticamente inconvenientes. (SGRECCIA, op. cit., p. 237-244).

\footnotetext{
${ }^{26}$ MYSCZUK, op. cit., p. 28.

${ }^{27}$ Pena apud MYSCZUK, op. cit., p. 28.
} 


\section{OS DIREITOS DA PERSONALIDADE}

\subsection{PERFIL HISTÓRICO DOS DIREITOS DA PERSONALIDADE}

Quando se inicia uma pesquisa sobre o perfil histórico dos direitos da personalidade na Antigüidade, o estudo deve ter a cautela ao apreciar os termos pessoa e personalidade no Direito Romano. Primeiramente, resta esclarecer que estes termos não tinham, naquele direito, o significado do direito atual.

No Direito Romano o termo pessoa não era sinônimo de sujeito de direito, muito menos, a personalidade era a aptidão para exercer direitos e contrair obrigações (capacidade). Pelo contrário, o Direito Romano não valorizava a individualidade da pessoa humana, mas sim a considerava parte de um todo social. ${ }^{28}$

Portanto, partindo de uma análise contextualizada do Direito Romano exigível faz-se negar a existência no Direito Romano dos direitos da personalidade com as características que os mesmos possuem no Direito Atual, pois na Antigüidade, a pessoa não tinha a mesma importância e valorização que o ordenamento jurídico a dispensa atualmente. ${ }^{29}$

Esta visão da pessoa humana como um ente integrante de um grupo sofreu mudanças e a partir da Idade Média se passou a valorizar a individualidade da pessoa humana, respeitando-a como ser dotado de dignidade. ${ }^{30}$

No decorrer da história o termo pessoa sempre evoluiu, porém foi só com liberalismo, no final do século XVII, que a proteção da pessoa humana passou a ser

${ }^{28}$ SZANIAWSKI, Elimar. Direitos da personalidade na antiga Roma. Revista de Direito Civil, Imobiliário, Agrário e Empresarial, São Paulo, v. 43, p. 34, jan./fev.1988.

${ }^{29}$ Sobre os conceitos do passado de pessoa e de personalidade ver também SIDON, J. M. Othon. PERSONALIDADE II. In: ENCICLOPÉDIA Saraiva de Direito. São Paulo: Saraiva, 19141981. v. 58, p. 214-226 e SZANIAWSKI. Direitos de personalidade e sua tutela..., p. 20-35.

${ }^{30}$ Foi o Cristianismo que criou a idéia de dignidade da pessoa humana, sendo que para Tomás de Aquino a pessoa era aquilo que era revestido de dignidade. (CORTIANO JUNIOR, Eroulths. Direitos da personalidade: direito à vida, ao próprio corpo e ao cadáver. Curitiba, 1993, p. 31. Dissertação de Mestrado - Departamento de Direito, Universidade Federal do Paraná.). 
reconhecida pelo Estado, em especial na Inglaterra que tinha um governo de monarquia constitucionalista. ${ }^{31}$

Em seguida a história foi premiada com a Revolução Francesa de 1789 quando, após a derrocada da monarquia absolutista, o liberalismo tomou conta da França com os seus ideais de liberdade, igualdade e fraternidade que se transplantaram para diversas Constituições Francesas, bem como para a tão famosa Declaração dos Direitos do Homem e do Cidadão, de 1789, e para tantas outras Declarações que se seguiram. $^{32}$

Este foi o nascedouro dos direitos humanos compreendidos como os direitos que protegem a pessoa humana dos arbítrios do Estado; os quais passaram a serem previstos constitucionalmente e a serem denominados de direitos fundamentais. A preponderância da previsão de proteção da pessoa humana somente no âmbito público estava em total consonância com os interesses econômicos dos revolucionários, ou seja, com os interesses da classe burguesa.

No âmbito privado reinava a autonomia privada com base no principio da igualdade (formal, é claro), sendo que neste campo a pessoa não dispunha de proteção específica, pois aí predominam os interesses econômicos. ${ }^{33}$

Contudo, aos poucos se constatou que, com a evolução da sociedade e das relações privadas, bem como após vários acontecimentos que demonstraram total desprezo pela raça humana - Duas Grandes Guerras, este sistema no qual a pessoa humana era tratada como um dos elementos da relação jurídica não mais poderia

${ }^{31}$ SZANIAWSKI. Direitos de personalidade e sua tutela ..., p. 25.

32 Declaração de Direitos de 1793; Declaração Universal dos Direitos do Homem da ONU de 1949, Convenção Européia dos Direitos do Homem e das Liberdades Fundamentais de 1950, entre outras.

${ }^{33}$ A legislação civil de diversos países, dentre eles a do Brasil - Código Civil de 1916, foi impregnada por estes valores consagrados na legislação francesa. Neste sentido Danilo Doneda afirma que "a liberdade era garantida, e dela defluiria também a proteção da liberdade econômica - a liberdade de contratar [...]. O direito à propriedade privada era garantido a todos, assim como a própria liberdade. [...]. Neste panorama, no inicio do século XIX, restou reavivada a summa divisio entre o direito privado e o direito público." (DONEDA, Danilo. Os direitos da personalidade no novo Código Civil. In: TEPEDINO, Gustavo [coord.]. A parte geral do novo Código Civil: estudos na perspectiva civil-constitucional. Rio de Janeiro: Renovar, 2002. p. 38). 
reinar, em detrimento dos valores primordiais do homem.

O resultado de tais constatações foi uma ruptura com os valores consagrados nas legislações civis anteriores, sendo que o direito contemporâneo, enraizado por concepções e ideais existenciais, centraliza todo direito na pessoa humana, não mais como um dos elementos da relação jurídica, mas sim como o núcleo do ordenamento. $^{34}$

Passa-se, então, lentamente, a se construir a doutrina dos direitos da personalidade, sendo que sua construção teórica surgiu apenas no final do século XIX, desenvolvida pela doutrina alemã, encabeçada por Otto Von Gierke.

Cautelosamente, o BGB alemão (1900) já previa o direito ao nome, bem como considerava como bens pessoais a vida, o corpo e a liberdade, porém não sistematizou a proteção desta categoria, sendo este um papel para a Constituição de Weimar (1919). Contudo, foi a Constituição Italiana de 1947 que concretizou grande avanço nas legislações sobre o assunto, tipificando expressamente os direitos da personalidade. ${ }^{35}$

Deve ressaltar-se, concluindo este breve perfil histórico dos direitos da personalidade, que mesmo após décadas de desenvolvimento doutrinário os juristas reconhecem que tal instituto ainda está eivado de dúvidas e discussões doutrinárias, ${ }^{36}$ que certamente perdurarão por mais algumas décadas.

${ }^{34}$ Razão pela qual se fala em repersonalização do direito civil.

${ }^{35}$ Posteriormente, o Código Civil Português de 1966 traz para a legislação civil uma regra geral de tutela da personalidade; e seguidamente, várias outras legislações, dentre elas a brasileira, como se analisará no item 1.3, consagraram normativamente o que já era de conhecimento do homem simples, que a pessoa humana deve ser sempre o centro do Direito.

${ }^{36}$ CORTIANO JUNIOR, Eroulths. Alguns apontamentos sobre os chamados direitos da personalidade. In: FACHIN, Luiz Edson [coord.]. Repensando fundamentos do direito civil brasileiro. Rio de Janeiro: Renovar, 1998. p. 42-43. 


\subsection{PERSONALIDADE E DIREITOS DA PERSONALIDADE}

Antes de analisar especificadamente os direitos da personalidade, necessário se faz adentrar na conceituação dos termos pessoa, personalidade e capacidade. A palavra pessoa, em seu sentido primitivo, correspondia ao verbo personare, fazer ressoar; sendo que no latim significava a máscara usada pelos atores romanos nas peças teatrais, que possuía uma abertura com lâminas que produziam um aumento no volume da voz.

Usando de analogia, o Direito emprega a expressão para designar o sujeito de direitos, aquele que desempenha no mundo jurídico os papéis previamente estabelecidos de contratante, de proprietário, de cônjuge. As codificações civis do século XIX, impregnadas pelo formalismo, pelo individualismo e pelo patrimonialismo da época, usavam daquela analogia e reduziam a pessoa a um dos elementos da relação jurídica, sendo considerada como uma categoria abstrata, vista simplesmente como sujeito de direitos.

Portanto, as expressões, pessoa e sujeito de direito, eram sinônimos perante o Direito Moderno, conseqüentemente, personalidade era uma qualidade jurídica, era a aptidão genérica para adquirir direitos e contrair obrigações, sendo necessário ressaltar que ainda hoje estes conceitos são adotados pela doutrina tradicional. ${ }^{37}$ Tais conceitos $^{2}$ abstratos eram suficientes para o Direito diante da perspectiva ideológica daquele momento histórico. ${ }^{38}$

${ }^{37}$ Caio Mário da Silva Pereira, semelhantemente a tantos outros doutrinadores (Arnoldo WALD, Orlando GOMES, entre outros), ensina que "a idéia de personalidade está intimamente ligada à de pessoa, pois exprime a aptidão genérica para adquirir direitos e contrair obrigações. [...] Como o homem é o sujeito de das relações jurídicas, e a personalidade a faculdade a ele reconhecida, diz-se que todo homem é dotado de personalidade." (grifos do autor) (PEREIRA, Caio Mário da Silva. Instituições de direito civil: introdução ao direito civil; teoria geral do direito civil. 19. ed. rev. atual. Rio de Janeiro: Forense, 2000, p. 141-142)

${ }^{38}$ Neste sentido Jussara Meirelles ao analisar o Código Civil de 1916 afirma que neste "a pessoa é um elemento científico, um conceito oriundo da construção abstrata do Direito." Ressalta ainda que "esse delineamento abstrato decorre, substancialmente, da noção de relação jurídica como base do Direito Civil", pois em razão desta noção "as pessoas são consideradas sujeitos, não porque reconhecidas a sua natureza humana e a sua dignidade, mas na medida em que a lei lhes atribui faculdades ou obrigações de agir, delimitando o exercício de poderes ou exigindo o cumprimento de 
Diante desta ordem de idéias, conclui-se que a legislação civil não tratava a pessoa como ser humano, portador de valores, ideais, sentimentos, necessidades, anseios etc., mas sim como um sujeito de direitos com aptidão para ser o proprietário, o contratante etc., excluindo, conseqüentemente, desta regulação, todos aqueles que não se enquadravam nestes papéis. ${ }^{39}$

Felizmente a visão de pessoa, como um dos elementos da relação jurídica, está sendo abandonada cotidianamente e o Direito Contemporâneo tem assumido efetivamente a pessoa como ser humano, como o "ser dotado de consciência e dignidade", ${ }^{40}$ passando a tutelá-lo sobre esta perspectiva, enraizando-o como o núcleo do ordenamento jurídico. ${ }^{41}$

Esta nova visão de pessoa - uma noção substancial e não abstrata ${ }^{42}$ - é produto do próprio desenvolvimento de nossa sociedade (evolução da ciência, tecnologia etc.), conforme já relatado.

A construção da doutrina dos direitos da personalidade é fruto desta nova concepção do direito contemporâneo que tem como núcleo do sistema a pessoa

deveres." (MEIRELLES, Jussara. O ser e o ter na codificação civil brasileira: do sujeito virtual à clausura patrimonial. In: FACHIN, Luiz Edson [coord.]. Repensando fundamentos do direito civil brasileiro. Rio de Janeiro: Renovar, 1998. p. 89).

39 Está é a razão pela qual Jussara MEIRELLES afirma que de um lado há a pessoa codificada ou sujeito virtual - aquele homem livre e proprietário - do lado oposto há o sujeito real, o ser humano constituído pela sua consciência, pela sua individualidade. (ibid., p. 91). Todo este individualismo e liberalismo extremos, bem como este patrimonialismo exacerbado é fruto das ideologias da época, das quais a Revolução Francesa foi uma das conseqüências.

${ }^{40}$ CORTIANO JUNIOR. Direitos da personalidade..., p. v.

41 Demonstrando esta nova concepção de pessoa e de personalidade do Direito Contemporâneo Eroulths Cortiano Junior afirma que "o centro nuclear do direito civil é a pessoa humana. Todo e qualquer instituto jurídico só tem razão de ser a partir do momento em que exista (e seja considerado) em função do homem. O próprio direito encontra sua razão de existir na noção de pessoa humana, que é anterior à ordem jurídica. Esta, construindo a noção de personalidade, o faz com base num dado pré-normativo, que é, ao mesmo tempo ontológico (a pessoa é) e axiológico (a pessoa vale). Não se pode confundir (sob o prisma metodológico), a idéia de sujeito de direito com a idéia de personalidade, que partem de premissas distintas, e têm funções distintas. Como o ponto de partida do direito é a noção de personalidade, pode-se dizer que todo o direito funciona em razão da pessoa humana. Neste prisma, nada mais correto do que a afirmação de que, na atualidade, mais importa o ser, e menos importa o ter." (CORTIANO JUNIOR. Alguns apontamentos..., p. 41-42).

${ }^{42} \mathrm{O}$ Direito abandona aquela neutralidade em face da realidade em nome da segurança jurídica e assume a necessidade de uma leitura interdisciplinar para a busca da realização da justiça. 
humana, sendo ela a preocupação central desta nova categoria, haja vista que os direitos da personalidade são aqueles inerentes à pessoa humana, sendo que todo homem os possuem devido a sua própria condição de ser humano.

Portanto, nas palavras de José Lamartine Corrêa de Oliveira e de Francisco José Ferreira Muniz, a categoria dos direitos da personalidade somente pode ser entendida "à luz de uma noção de pessoa que supere o esvaziamento a que tal noção foi submetida pela carga histórica de uma educação jurídica positivista a pesar sobre sucessivas gerações de cultores do Direito",43 sendo assim, somente uma noção prénormativa de pessoa levará o jurista a entender a amplitude e relevância desta categoria.

Veja-se, após esta reviravolta do Direito Contemporâneo, a pessoa deixa de ser mero sujeito de direitos para passar a ser visto como ser humano dotado de consciência, sentimentos, dignidade, anseios etc. e a personalidade passa a ser vista sob dois enfoques necessários: um jurídico - como capacidade - e outro natural como conjunto de atributos fundamentais sem os quais o homem não existe, ou seja, atributos inerentes à condição de ser humano.

Exemplificando estes dois enfoques da palavra personalidade, indispensável é a transcrição dos ensinamentos do jurista San Tiago Dantas: ${ }^{44}$

Quando se fala em direitos da personalidade, não se está se identificando aí a personalidade como a capacidade de ter direitos e obrigações; estamos então considerando a personalidade como um fato natural, como um conjunto de atributos inerentes à condição humana; estamos pensando num homem vivo e, não, nesse atributo especial do homem vivo, que é a capacidade jurídica, em outras ocasiões identificada como a personalidade. (grifos do autor)

${ }^{43}$ OLIVEIRA, José Lamartine Corrêa de; MUNIZ, Francisco José Ferreira. O estado de direito e os direitos da personalidade. Revista da Faculdade de Direito da Universidade Federal do Paraná, Curitiba, v. 19, p. 230, 1978-1980.

${ }^{44}$ Neste sentido Gustavo Tepedino afirma que a personalidade pode ser considerada sob dois aspectos, primeiro como capacidade, sendo este "o ponto de vista estrutural (atinente à estrutura das situações jurídicas subjetivas), em que a pessoa, tomada em sua subjetividade, identifica-se como o elemento subjetivo das situações jurídicas" e o outro aspecto, que se identifica com a acepção natural de San Tiago Dantas, visualizaria "a personalidade como conjunto de características e atributos da pessoa humana, considerada como objeto de proteção por parte do ordenamento jurídica." (TEPEDINO, Gustavo. Temas de direito civil. Rio de Janeiro: Renovar, 2001, p. 27). 
[...]

Quer dizer que a palavra personalidade pode ser tomada em duas acepções: numa acepção puramente técnico-jurídica ela é a capacidade de ter direitos e obrigações e é, como muito bem diz Unger, o pressuposto de todos os direitos subjetivos e, numa outra acepção, que se pode chamar acepção natural: é o conjunto dos atributos humanos e não é identificável. ${ }^{45}$

Conclui-se que é sobre esta nova perspectiva conceitual que se deve analisar a categoria dos direitos da personalidade, bem como todo o Direito.

A personalidade, na sua acepção natural, é ilimitável, sendo impossível o Direito prever limitações ao seu desenvolvimento completo, sendo que todos os seres humanos são dotados de tal personalidade; enquanto, à capacidade - personalidade no sentido técnico jurídico - o Direito a todo instante impõe limitações que muitas vezes são até mesmo em razão da proteção desta - da personalidade no seu conceito natural. $^{46}$

Necessário se faz agora analisar a conceituação destes direitos, tarefa árdua em razão das já mencionadas divergências doutrinárias, motivo pelo qual se transcreverá conceitos de alguns juristas estrangeiros e brasileiros.

Carlos Alberto Bittar afirma que se consideram "como da personalidade os direitos reconhecidos à pessoa humana tomada em si mesma e em suas projeções na sociedade, previstos no ordenamento jurídico exatamente para a defesa de valores inatos no homem, como a vida, a higidez física, a intimidade, a honra, a intelectualidade e outros tantos". ${ }^{47}$

Já o jurista Gustavo Tepedino entende que se compreendem "sob a denominação de direito de personalidade, os direitos atinentes à tutela da pessoa

${ }^{45}$ DANTAS, San Tiago. Programa de direito civil: aulas proferidas na Faculdade Nacional de Direito. Rio de Janeiro: Rio, 1942-1945, p. 192.

${ }^{46}$ Neste sentido José Lamartine Corrêa de OLIVEIRA e Francisco José Ferreira MUNIZ afirmam que, em razão da própria noção pré-normativa de pessoa (ontológica e axiologicamente falando), "a personalidade é uma noção insuscetível de gradações ou restrições. A capacidade de direito, ao contrário, pode sofrer restrições ou limitações por parte da ordem positiva." (op. cit., p. 231).

47 BITTAR, Carlos Alberto. Os direitos da personalidade. 5. ed. rev. atual. aum. por Eduardo C. B. Bittar. Rio de Janeiro: Forense Universitária, 2001, p. 1. 
humana, considerados essenciais à sua dignidade e integridade". ${ }^{48}$

Após análise dos conceitos transcritos se considera possível aventurar-se em uma tentativa de conceituação: os direitos da personalidade são aqueles direitos inerentes à pessoa, aqueles indispensáveis, os quais o homem possui pelo simples fato de ser homem, em razão de sua própria natureza humana.

Agora se analisará a questão do objeto da personalidade, sendo necessário remeter o leitor aos conceitos já apontados de pessoa, personalidade e capacidade, bem como as acepções jurídica e natural do termo personalidade, ressaltando que é com base nesta acepção que se deve analisar o objeto destes direitos, para não se ceder novamente a objeção de confusão entre sujeito e objeto.

Primeiramente, conforme Orlando Gomes, a definição do direito de personalidade reclama "o alargamento do conceito jurídico de bem, que lhe reconheça significação diversa da que se lhe atribui em Economia". ${ }^{49}$ Conseqüentemente, considerando-se bem toda utilidade material ou não que incidam na faculdade de agir do sujeito, não se pode, em hipótese alguma, recusar que as projeções físicas ou psíquicas da personalidade sejam tuteladas pelo ordenamento jurídico como objeto dos direitos da personalidade.

Neste sentido afirma o professor Eroulths Cortiano Junior que "o objeto dos direitos da personalidade são as manifestações essenciais da personalidade humana, projeções desta no mundo social, sem as quais falta dignidade suficiente à pessoa para ser reconhecida como tal na sociedade". ${ }^{50}$

Com relação aos caracteres destes direitos, por entender mais criteriosa e científica, adotar-se-á a especificação do professor Eroulths Cortiano Junior que, destacando a inexistência de unanimidade na doutrina ao assinalar as características dos direitos da personalidade, esclarece que "com fundamento nas pesquisas

${ }^{48}$ TEPEDINO, op. cit., p. 23.

${ }^{49}$ GOMES, Orlando. Direitos de personalidade. Revista Forense, Rio de Janeiro, v. 216, p. 7, out./dez. 1966.

${ }^{50}$ CORTIANO JUNIOR, Direitos da personalidade..., p. 7. 
empreendidas, podemos destacar as que têm merecido mais aceitação: generalidade, extrapatrimoniabilidade, absolutismo e indisponibilidade". ${ }^{51}$

Outro ponto de controvérsias doutrinárias é a "técnica de inserção" ${ }^{52}$ destes direitos no ordenamento: via tipificação de cada direito em conformidade com os atributos já aferíveis pelo Direito; ou através da previsão de um único direito, chamado direito geral da personalidade. ${ }^{53}$

A primeira corrente, denominada de pluralista, afirmava que sendo os bens individualizados de acordo com as necessidades, conseqüentemente, deverá haver um bem para cada necessidade e um direito correspondente a cada um dos bens. Alegam que a necessidade de viver de forma honrada não se confunde, por exemplo, com a necessidade de ter sua identidade respeitada e vice-versa.

Em contraposição a esta tese, a teoria monista, argumenta que a personalidade é una e suas diversas projeções se interligam para se concretizar em um valor unitário que é a pessoa. Contra o argumento da amplitude de um direito geral da personalidade que supostamente poderia ser perigosa, pois poderia dificultar a proteção da personalidade; alegam que os limites deste direito seriam auferidos no caso concreto, através de uma ponderação de valores e interesses.

Contudo, claro se mostra que a tipificação tem o condão de estagnar o Direito em face da realidade dinâmica e freqüentemente inovada pelo progresso científico e tecnológico que a cada dia "inventa" uma forma de agressão aos direitos da personalidade. Em razão do exposto, acredita-se que se deve aderir ao entendimento de Eroulths Cortiano Junior ${ }^{54}$ que afirma que a tipificação e a previsão de um direito geral de personalidade devem se complementar para que o Direito dispense a pessoa

${ }^{51}$ (Ibid., p. 10). Não se analisará cada uma destas características por considerar dispensável em razão do limite da presente pesquisa que não tem o condão de ser completa.

${ }^{52}$ Expressão utilizada pelo jurista Danilo DONEDA (op. cit., p. 42).

${ }^{53}$ Tais correntes doutrinárias se desenvolveram com grande ênfase na Alemanha, sendo que lá foi que se desenvolveu a teoria monista ou do direito geral da personalidade. (SZANIAWSKI. Direitos de personalidade e sua tutela..., p. 28-34).

${ }^{54}$ CORTIANO JUNIOR. Direitos da personalidade..., p. 20. 


\section{OS DADOS GENÉTICOS E O DIREITO À PRIVACIDADE: \\ A DECLARAÇÃO UNIVERSAL SOBRE O GENOMA HUMANO E OS DIREITOS HUMANOS}

humana uma proteção integral e efetiva.

É pertinente ressaltar que não existe, entre os defensores da teoria tipificadora, uma unanimidade na classificação destes direitos, sendo que cada doutrinador estabelece uma classificação diferenciada mantendo algumas semelhanças.

Para somente exemplificar, haja vista que o objetivo deste trabalho é analisar detidamente somente o direito à privacidade, cita-se a classificação de Limongi França $^{55}$ que os engloba em três grupos: ${ }^{56}$ direito à integridade física; ${ }^{57}$ direito à integridade intelectual; ${ }^{58}$ e direito à integridade moral. ${ }^{59}$

\subsection{O DIREITO À PRIVACIDADE}

Dentro da classificação apresentada por Limongi França, o direito à privacidade (mesmo que o autor não utilize esta denominação) se enquadra no grupo do direito à integridade moral, sendo que, conforme o Prof. Antonio Carlos Efing, ${ }^{60}$ o direito à privacidade deve ser considerado gênero do qual o direito à intimidade ${ }^{61}$ é espécie. Aquele se refere a todas as manifestações da esfera íntima, dizendo respeito "a

${ }^{55}$ FRANÇA, Rubens Limongi. Direitos privados da personalidade. Revista dos Tribunais, São Paulo, v. 370, p. 10-11, ago. 1966. categoria.

${ }^{56}$ Reconhece, porém, o autor que por vezes tais direitos participam de mais de uma

${ }^{57}$ Que agruparia o direito à vida e aos alimentos; o direito sobre o próprio corpo (vivo e morto); o direito sobre o corpo alheio (vivo e morto); o direito sobre partes separadas do corpo (vivo e morto).

${ }^{58}$ Que concentraria o direito à liberdade de pensamento; o direito pessoal de autor científico; o direito pessoal de autor artístico; o direito pessoal de inventor.

${ }^{59}$ Que congregaria o direito à liberdade civil, política e religiosa; o direito à honra; o direito à honorificência; o direito ao recato; o direito ao segredo pessoal, doméstico e profissional; o direito à imagem; o direito à identidade pessoal, familiar e social.

${ }^{60}$ EFING, Antonio Carlos. Bancos de dados e cadastros de consumidores. São Paulo: RT, 2002, p. 50-52.

${ }^{61}$ Contrariamente, Carlos Alberto BITTAR os entende como conceitos sinonímicos. (op. cit., p. 106-107). 
todos aqueles costumes pessoais que cabe somente ao individuo a escolha de sua divulgação ou não", representando "a disposição do cidadão sobre todas as informações a seu respeito". ${ }^{62}$

Portanto, o núcleo do direito à privacidade é "a faculdade concedida ao indivíduo, a todos oponível, de subtrair à intromissão alheia e ao conhecimento de terceiros certos aspectos da sua vida que não deseja participar a estranhos, ou seja, de decidir o que vai desnudar aos outros, de que forma e em que circunstâncias". ${ }^{63}$

Já o direito à intimidade ${ }^{64}$ deve ser considerado somente parcela do direito à privacidade, parcela essa mais interna do ser, referente à sua essência, ao seu âmago, a sua esfera intersubjetiva. ${ }^{65}$

Ressalta-se que o direito à privacidade era desconhecido dos antigos, pois as suas vidas se transcorriam nos espaços públicos, sendo que o reconhecimento deste direito surge "historicamente somente quando a burguesia se universaliza como classe social, e o avanço tecnológico aumenta as possibilidades de violação da cidadela da intimidade da pessoa humana". ${ }^{66}$

Ressalta, ainda, o jurista Edilsom Pereira de Farias, que nem mesmo as primeiras declarações de direitos fizeram menção ao direito à intimidade, sendo que "o primeiro texto internacional a proteger a intimidade foi a Declaração Americana dos Direitos e Deveres do Homem, aprovada em Bogotá, no dia 2 de maio de 1948, no seu

${ }^{62}$ EFING, op. cit., p. 51-52.

63 (CARVALHO, Ana Paula Gambogi. O consumidor e o direito à autodeterminação informacional. Revista de Direito do Consumidor, São Paulo, n. 46, p. 83-84, abr. 2003). Necessário se faz ressaltar que a jurista Ana Paula Gambogi Carvalho adota as expressões direito à intimidade e à vida privada por serem estes os termos empregados pela CF/1988, ressaltando que quaisquer diferenciações entre estes dois termos não apresentam importância na esfera prática, sendo que emprega também a expressão direito à privacidade como gênero do qual, aquelas fazem parte.

${ }^{64}$ Conforme o conceito do Dicionário Aurélio, intimidade é a qualidade de intimo, sendo este o que está muito dentro, que atua no interior, o âmago.

${ }^{65}$ EFING, op. cit., p. 52.

${ }^{66}$ FARIAS, Edilsom Pereira de. Colisão de direitos. A honra, a intimidade, a vida privada e a imagem versus a liberdade de expressão e informação. Porto Alegre: Fabris, 1996, p. 111. 
art. $5^{\circ} . " .67$

Conforme acima citado, o direito à privacidade teve sua origem após o advento da era tecnológica, sendo que é em virtude dos avanços tecnológicos e agora dos avanços no âmbito das ciências biomédicas (as quais somente foram conquistadas em razão do desenvolvimento tecnológico já existente e ainda possível), que se é possível afirmar que as possibilidades de sua afronta são inimagináveis.

Neste sentido e de forma brilhante assim Paulo José da Costa Junior se manifesta sobre esta correlação:

O processo de corrosão das fronteiras da intimidade, o devassamento da vida privada, tornou-se mais agudo e inquietante com o advento da era tecnológica. [...] A revolução tecnológica, sempre mais acentuadamente, ganha um dinamismo próprio, desprovido de diretrizes morais, conduzido por um "cientificismo" ao qual são estranhas e mesmo desprezíveis quaisquer preocupações éticas, metafísicas, humanísticas. Torna-se cega e desordenada, subtraindo-se ao controle até mesmo dos sábios, que a desencadeiam.

O crédito que toda a Humanidade abre à ciência ainda é ilimitado e prenhe de esperanças, mas já não se admite que o ingresso de nossa civilização na era da cibernética total possa operar-se à margem da reflexão crítica. Especialmente quando se sabe hoje que o progresso técnico interfere até mesmo na revolução biológica, modificando o seu curso. ${ }^{68}$

Sendo um direito de personalidade ou uma de suas projeções (conforme a teoria adota, de acordo com o já mencionado no item anterior) o direito à privacidade é inalienável, imprescritível e irrenunciável, sendo que o seu respeito visa especificamente a mais ampla e completa proteção do ser humano, em toda a sua dignidade, considerando e adotando o princípio da dignidade da pessoa humana como cláusula geral da personalidade.

Como todo direito há de se ressaltar que o direito à privacidade não é absoluto, sendo que sofrerá limitações, como, por exemplo, pelo interesse coletivo, pela liberdade de expressão etc.. Tais limitações serão verificadas no caso concreto, sendo imprescindível uma análise com fulcro no princípio da proporcionalidade,

\footnotetext{
${ }^{67}$ Ibid.

${ }^{68}$ COSTA JUNIOR, Paulo José da. O direito de estar só: tutela penal da intimidade. São Paulo: RT, 1995, p. 22.
} 
ponderando-se os bens jurídicos em conflito e verificando qual deverá prevalecer em face do outro. ${ }^{69}$

A nossa Constituição Federal ${ }^{70}$ prevê, expressamente, em consonância com os valores por ela consagrados, a proteção do direito à privacidade (incluindo o direito à intimidade e à vida privada) no seu art. $5^{\circ}$., inciso $\mathrm{X},{ }^{71}$ bem como em diversos outros dispositivos que buscam resguardar aspectos particulares da vida dos indivíduos, assegurando a inviolabilidade da casa (inciso XI), do sigilo de dados, da correspondência e das comunicações (inciso XII), entre outros dispositivos, alguns dos quais prevêem instrumentos processuais para assegurar o direito à privacidade. ${ }^{72-73}$

${ }^{69}$ O jurista Edilsom Pereira de FARIAS em livro intitulado "Colisão de direitos: a honra, a intimidade, a vida privada, a imagem versus a liberdade de expressão e informação", após analisar no primeiro capítulo a questão relacionada às normas jurídicas (regras e princípios), distinguindo-as, bem como apontando as funções dos princípios para em seu segundo capitulo analisar expressamente os direitos fundamentais, no derradeiro capítulo analisa a questão da colisão de direitos, evidenciando que a solução de tal conflito deverá ser baseada nos fundamentos da colisão de princípios, ou seja, jamais haverá incompatibilidade total entre os direitos, mas sim concorrência, sendo que, como os princípios, os direitos conflitantes deverão ser cumpridos proporcionalmente às condições reais e jurídicas existentes no caso concreto. (op. cit., passim).

${ }^{70}$ Foi com a promulgação da Constituição de 1988 que se deu o passo definitivo para o abandono do patrimonialismo que regeu nosso Código de 1916 e a acolhida do personalismo com a tutela dos direitos da personalidade, dando grande relevo à dignidade da pessoa humana, pois esta foi elevada a princípio fundamental da República (art. $1^{\circ}$., III da Constituição Federal). Baseando-se nesta nova perspectiva apresentada pela Constituição Federal, bem como em virtude da própria previsão da dignidade da pessoa humana como fundamento da República é que muitos doutrinadores afirmam que aí está presente uma cláusula geral da personalidade. Neste sentido o professor Gustavo TEPEDINO (op. cit., p. 48).

71 "X - são invioláveis a intimidade, a vida privada, a honra e a imagem das pessoas, assegurado o direito à indenização pelo dano material ou moral decorrente de sua violação".

72 "LXXII - conceder-se-á habeas-data: a) para assegurar o conhecimento de informações relativas à pessoa do impetrante, constantes de registros ou bancos de dados de entidades governamentais ou de caráter público; b) para a retificação de dados, quando não se prefira fazê-lo por processo sigiloso, judicial ou administrativo". A análise do habeas data será efetivada abaixo.

${ }^{73} \mathrm{O}$ atual Código Civil que entrou em vigor em 2003 buscou uma sistematização na legislação infraconstitucional sobre os direitos da personalidade, mas que não se pretende exaustiva, limitando-se a prever seus princípios fundamentais, conforme menciona o jurista José Carlos Moreira Alves. (ALVES, José Carlos Moreira. A parte geral do projeto do Código Civil. Disponível em: http://www.cjf.gov.br/revista/numero9/artigo1.htm Acesso em: 22 jul. 2002). Ressalta-se que o art. 21 do atual Código Civil prevê que "a vida privada da pessoa natural é inviolável". 


\section{DADOS GENÉTICOS versus DIREITO À PRIVACIDADE: A Declaração Universal sobre o Genoma Humano e Direitos Humanos}

No decorrer do presente trabalho já se pode constatar, em uma primeira visão, as amplas possibilidades de ofensa ao direito à privacidade que o acesso, indiscriminado e ilegal, aos dados genéticos de uma determinada pessoa pode causar.

Ressalta-se que a discriminação e a eugenia como formas de marginalização social não são assuntos recentes, ${ }^{74}$ sendo que muito antes de se cogitar da possibilidade de se ter acesso às informações genéticas de uma determinada pessoa, através das técnicas de engenharia genética, a humanidade já foi ou é assombrada por tais práticas repugnantes.

Veja-se, com a compreensão do genoma humano o tratamento de doenças genéticas está deveras facilitado, sendo que o efeito mais imediato do PGH é a disponibilidade de testes genéticos, sendo que "esses testes podem confirmar diagnóstico, identificar portadores (sadios) de um gene patogênico e fornecer informações pré-sintomáticas, incluindo riscos de doenças futuras e morte precoce. Além disso, podem também revelar informações não somente sobre o individuo mas sobre seus familiares". ${ }^{75}$

Portanto, "é multíplice o emprego da engenharia genética com finalidade de diagnóstico e nestes últimos anos aumento o leque de novas aplicações", sendo que, além do diagnóstico genético pré-natal (que poderá a levar a controvérsia do aborto terapêutico), "desenvolvem-se aplicações a respeito do adulto com a finalidade de

${ }^{74}$ Em texto intitulado "Por uma ética para a engenharia genética" Roberto Chacon de Albuquerque apresenta a experiência americana, nórdica, alemã e chinesa de procedimentos com fins claramente eugênicos, sendo que se pode citar, por exemplo, a prática americana, fundada em leis, de esterilização profilática de deficientes físicos e mentais, sem necessidade de consentimento e a prática alemã (sem mencionar as práticas nazistas) de esterilizar pessoas portadoras de doenças hereditárias (isto em meados de 1933), as quais eram classificadas pela Lei para a Prevenção do Nascimento de Descendentes com Doenças Hereditárias, podendo citar-se como exemplo: fracos de espírito; cegueira hereditária; surdez hereditária, etc.. (ALBUQUERQUE, Roberto Chacon de. Por uma ética para a engenharia genética. Revista de Direitos Difusos: Bioética e Biodiversidade, São Paulo, v. 12, p. 1.635-1.642, abr. 2002).

\footnotetext{
${ }^{75}$ PASSOS-BUENO, op. cit., p. 151.
} 
confirmação de doenças de origem supostamente genética, na fase pré-matrimonial e pré-concepcional para se avaliar o risco que correm os potenciais portadores sãos de procriar filhos doentes, na área civil para a confirmação da paternidade, na área penal para identificar o réu de delitos, bem como no âmbito dos screening." Esse âmbito se refere principalmente aos casos ocorridos no campo da medicina do trabalho, em forma de testes de aptidão generalizados para um determinado ambiente de trabalho. ${ }^{76}$

Contudo, tais possibilidades, mesmo que por diversas vezes benéficas, podem acarretar as questões antes mencionadas, ou seja, discriminação, exclusão social etc., necessitando de uma atuação rígida do Direito (ou do Biodireito).

Analisando mais detidamente as conseqüências "maléficas", por assim dizer, das técnicas de engenharia genética Elio Sgreccia reconhece que vários são os "riscos e problemas de natureza ética relacionados precisamente com as possibilidades de novos conhecimentos de tipo genético". ${ }^{77}$

O autor cita diversos problemas relacionados a este âmbito, ressaltando que o primeiro e um dos mais importantes é a possibilidade de aplicação mais ampla do diagnóstico pré-natal com finalidade eugênica, pois ao ser possível se conhecer "mais amplamente na fase pré-natal genes doentes e sujeitos portadores deles, a tendência de eugenia pode receber uma aplicação maior." Cita ainda o autor outro problema relacionado aos dados genéticos: a construção de bancos de dados sobre as pessoas que se submeteram à pesquisa e a possibilidade de má-utilização destas informações (transferência com fins mercadológicos a particulares, às companhias de seguros etc.). ${ }^{78}$

Também analisando tais questões relacionadas à engenharia genética, mas mais detidamente a relacionada ao direito à privacidade e os dados genéticos, Ana

${ }^{76}$ (SGRECCIA, op. cit., p. 225). Ressalta-se que as finalidades do emprego das conquistas genéticas não se resumem as finalidades diagnósticas, sendo que tais técnicas são empregadas também com finalidade terapêuticas, produtivas, alterativas e experimentais. (Ibid.) Contudo, o presente trabalho ressalta somente o âmbito do diagnóstico em razão do seu objetivo primordial: abordar o direito à privacidade em face dos dados genéticos.

\footnotetext{
${ }^{77}$ Ibid., p. 244.

${ }^{78}$ Ibid., loc. cit.
} 
Paula Myszczuk afirma que "as investigações sobre o genoma humano têm como objeto mediato e imediato o conhecimento das características do DNA humano, de seus componentes integrantes, suas funções e sua participação na transmissão da herança genética. ${ }^{79}$ Ressalta ainda, citando Celeste Leite dos Santos Pereira Gomes e Sandra Sorgi, que "a leitura do genoma é objetada na medida em que o indivíduo se sujeita a ficar exposto a terceiros em sua intimidade biológica mais profunda. Dir-se-ia que o direito à intimidade está ínsito na proteção genérica e ampla do direito à intimidade contida no art. 5, X, da Constituição Federal". ${ }^{80}$

Analisando estas questões, Volnei Garrafa, Sergio Ibiapina Ferreira Costa e Gabriel Oselka informam que "principalmente nos EUA, as conseqüências resultantes são da maior seriedade social, pois empregadores e empresas seguradoras [...] e também escolas e mesmo Cortes de Justiça, buscam respostas de alta eficácia, com custos mais baixos e menores riscos. Para tanto, utilizam-se cada vez mais da técnica dos testes" [preditivos]. Salientam ainda os autores que tais testes "passam a ir além dos procedimentos médicos, criando verdadeiras categorias sociais, empurrando o individuo para quadros estatísticos. Os problemas sociais são reduzidos às suas dimensões biológicas". ${ }^{81}$

E arrematam os autores que "o indivíduo-cidadão passa a ser desconsiderado e criam-se 'categorias de indivíduos', os pacientes/coletivos da nova medicina. Mesmo na ausência de sintomas, o risco genético é endeusado como a própria doença". ${ }^{82}$

Portanto, analisando detidamente o conceito de direito à privacidade, o âmbito das técnicas de engenharia genética que têm finalidades diagnósticas e as diversas conseqüências do conhecimento das informações genéticas humanas, constata-se claramente que os dados genéticos, como informações diretamente relacionadas ao ser

${ }^{79}$ MYSZCZUK, op. cit., p. 93.

${ }^{80}$ Gomes e Sorgi apud MYSZCZUK, op. cit., p. 93-94.

${ }^{81}$ GARRAFA, Volnei; COSTA, Sérgio Ibiapina Ferreira; OSELKA, Gabriel. A bioética no Século XXI. Bioética, Brasília, v. 7, n. 2, p. 211, 1999.

${ }^{82}$ Ibid. 
humano, são integrantes da esfera íntima do homem, devendo ser protegidos, ${ }^{83}$ principalmente em face das disposições internacionais (através de convenções internacionais, declarações universais etc.) e sobremaneira em face das disposições constitucionais brasileiras já analisadas.

Foi possível, através desta análise superficial, constatar a amplitude do tema proposto, razão pela qual se buscou delimitar o âmbito de exame da proteção dos dados genéticos a apreciação das disposições da Declaração Universal sobre o Genoma Humano e os Direitos Humanos. ${ }^{84}$

A Declaração Universal sobre o Genoma Humano e os Direitos Humanos foi aprovada pela XXIX Conferência da UNESCO, com a presença de 186 Estados em 11/11/1997, sendo considerada fruto de um largo e meditado processo de elaboração, constatando que, diante dos avanços das investigações genéticas e seu impacto nos direitos humanos, as meras normas nacionais eram insuficientes, sendo imprescindível que tais fatos fossem regulamentados no âmbito internacional. ${ }^{85}$

Verifica-se que a Declaração se inicia com um capítulo intitulado "A dignidade humana e o genoma humano". Pode precisar-se que é com base neste valor/princípio que tal diploma internacional se funda, sendo o princípio da dignidade da pessoa humana, conforme Salvador Darío Bergel, converte-se "en guía insoslayable para interpretar y aplicar los principios que establece". ${ }^{86}$

Para o tema ora proposto se verifica a importância de se alçar o valor/princípio

${ }^{83}$ Sempre se deve ressaltar, conforme já efetivado, que inexistem direitos absolutos.

${ }^{84}$ Ressalta-se que vários assuntos ainda poderiam ser abordados como, por exemplo, o exame da Declaração Internacional sobre os Dados Genéticos Humanos; o exame dos dados genéticos em face do direito à privacidade apontando as suas relações com os princípios bioéticos, mais precisamente com o princípio da autonomia, pois o direito à privacidade está diretamente relacionado ao respeito à autonomia da pessoa, pois cabe a ela, e somente a ela, decidir se quer divulgar aspectos da sua privacidade e a quem quer divulgar; a questão do dever de segredo do profissional da área de medicina, analisando também as disposições extralegais (Resoluções do CRM, etc.), entre tantos outros pontos de extrema relevância para o tema, mas que no estrito âmbito deste artigo serão relegados a outro estudo mais aprofundado.

${ }^{85}$ BERGEL, Salvador Darío. Bioética, Genética y Derechos Humanos: la Declaración de la Unesco. Bioética. Brasília, v. 7, n. 2, p. 165, 1999.

${ }^{86}$ (Ibid., p. 167). Ressalta ainda o autor que esta invocação à dignidade da pessoa humana explica o vínculo que seu titulo estabelece entre direitos humanos e genoma humano. 
da dignidade da pessoa humana como o fundamento desta declaração internacional, pois, conforme já mencionado anteriormente, mesmo que de forma superficial, o princípio da dignidade da pessoa humana é considerado atualmente como cláusula geral da personalidade, sendo que se pode considerá-lo como o norte dos demais direitos da personalidade expressamente estabelecidos na legislação nacional, como, por exemplo, o direito à privacidade.

Voltando os olhos à declaração, se destacam, em consonância com o referido autor, o princípio da não-discriminação com fundamento nas características genéticas do indivíduo (art. $2^{\circ}$. e art. $6^{\circ}$.), ${ }^{87}$ sendo que a proteção da confidencialidade dos dados genéticos referida expressamente no art. $7^{\circ}$. demonstra claramente que uma das preocupações do referido diploma internacional é que os dados genéticos não sejam utilizados para fins ilícitos e abusivos que atinjam diretamente os direitos da personalidade (ou os direitos fundamentais ou os direitos humanos ${ }^{88}$ ).

Outrossim, acrescente-se a análise, ainda que superficial, a necessidade de consentimento prévio, livre e esclarecido não só aos fins da investigação, como ao tratamento e ao diagnóstico relacionado com o genoma humano. Ou seja, no que tange ao diagnóstico, caberá ao indivíduo, no exercício da sua autonomia, determinar o acesso, circulação e utilização dos seus dados genéticos.

Contudo, adverte Salvador Darío Bergel que "la creciente utilización de la información genética con finalidades ajenas a la clínica pone en tela de juicio el solo requerimiento del consentimiento informado como forma de resguardar la libertad del individuo y su derecho a la autodeterminación". ${ }^{89}$

${ }^{87}$ Salienta, neste ponto, Salvador Darío Bergel que tal princípio ressalta que não se pode reduzir o ser humano as suas características genéticas e conclui afirmando que "de persistir en esta visión focalizada, caeríamos en una nueva clase de discriminación social", advertindo que "existen raíces históricas que apuntan a una sobrevaluación de la constitución genética en el comportamiento humano, que en el pasado fueron utilizadas como instrumento de opresión social y justificación 'científica’ para aventuras racistas." (Ibid., p. 168)

${ }^{88}$ Por se considerar desnecessário para os limites do presente trabalho se prescindirá da analise da diferenciação destas categorias.

${ }^{89}$ (BERGEL, op. cit., p. 170). Ressalta o autor que não seria possível confiar apenas nas decisões individuais quando os fatos demonstram as diversas formas de coação social que podem constranger uma pessoa a ceder a sua própria informação genética, como, por exemplo, no âmbito das 
Analisando o princípio da confidencialidade expresso na referida declaração, ${ }^{90}$ se constata a grande preocupação demonstrada com a má utilização das informações genéticas, pois dentro do conceito de privacidade se inclui o de confidencialidade que se traduz no direito do indivíduo a determinar as circunstâncias nas quais deve ser revelada a informação genética e a quem se deve revelar.

Outrossim, tais informações genéticas não somente afetam o seu portador como também direta ou indiretamente terceiros (familiares, cônjuge etc.), bem como podem se tornar instrumentos bastante perigosos em mãos erradas, razão pela qual se torna imprescindível a sua proteção.

\section{CONSIDERAÇÕES FINAIS}

Antes de se partir para algumas considerações, com o intuito de finalizar o presente artigo, resta imprescindível novamente advertir que, diante da imensidão de possibilidades e assuntos relacionados ao tema, não se objetivou em momento algum esgotar a análise, pois, conforme já demonstrado, vários pontos não foram examinados.

Contudo, após esta análise, provavelmente, demonstrou-se a relevância do tema nos dias atuais, principalmente quando se constata que a humanidade vive na era da informação, sendo que todo o nosso sistema capitalista é fundado no poder da informação, razão pela qual se entende que a informação genética a respeito de um indivíduo se constitui um precioso poder nas mãos de terceiros.

Não há como se negar que a nossa sociedade é eminentemente capitalista e, conseqüentemente, de consumo. Não é de se surpreender que todas as "novidades"

relações trabalhistas, na contratação de seguros e de serviços de saúde, etc.). (Ibid.).

90 "Art. $7^{\circ}$. Os dados genéticos relativos a pessoa identificável, armazenadas ou processadas para efeitos de pesquisa ou qualquer outro propósito de pesquisa, deverão ser mantidos confidenciais nos termos estabelecidos na legislação." 
propiciadas pelo desenvolvimento da ciência biomédica se tornem - como de fato estão se tornando - produtos em nossa sociedade de consumo. Por via de conseqüência, o objetivo que deveria ser o primordial no desenvolvimento da ciência proporcionar melhor qualidade de vida ao ser humano - fica relegado a um segundo plano, assumindo o lucro a posição central.

Ou seja, quando os interesses econômicos estão em jogo, em regra eles comandam as questões relacionadas à informação genética, abandonando-se a relevância dos interesses do indivíduo e, conseqüentemente, os seus direitos humanos assegurados há décadas.

Daí a importância de se discutir tal tema e de demonstrar, se possível, as incomensuráveis possibilidades de mau uso destas informações que diretamente afrontam os direitos da personalidade, em especial o direito à privacidade.

A proteção do direito à privacidade em face dos dados genéticos é imprescindível, sendo que as conseqüências advindas desses progressos nas áreas biomédicas clamam urgentemente pela criação de normas e instrumentos de resguardo desse direito, sob pena de se dar guarida a interesses discriminatórios, eugênicos, comerciais etc.

\section{REFERÊNCIAS}

ALBUQUERQUE, Roberto Chacon de. Por uma ética para a engenharia genética. Revista de Direitos Difusos: Bioética e Biodiversidade, São Paulo, v. 12, p. 1.6351.642, abr.2002.

ALVES, José Carlos Moreira. A parte geral do projeto do Código Civil. Disponível em: http://www.cjf.gov.br/revista/numero9/artigo1.htm Acesso em: 22 jul.2002).

AMARANTE, Aparecida I. Responsabilidade civil por dano à honra. 3. ed. rev. atual. Belo Horizonte: Del Rey, 1996.

ARENDT, Hannah. Origens do totalitarismo. Trad. Roberto Raposo. São Paulo: 
Companhia das Letras, 1998.

BARBOZA, Heloisa Helena. Princípios da bioética e do biodireito. Bioética, v. 8, n. 2, p. 209-216, 2000. Disponível em: <http://www.direito.médico.vilabol.uol.com.br/heloisa.htm> Acesso em: 8 mar.2005.

BARRETO, Vicente de Paulo. Bioética, biodireito e direitos humanos. Revista Ethica, v. $\quad 5, \quad$ n. $\quad 1, \quad 1998 . \quad$ Disponível em http://www.dhnet.org.br/direitos/direitosglobais/paradigmas_textos/ v_barreto.html. Acesso em: 2 dez. 2004.

BERGEL, Salvador Darío. Bioética, Genética y Derechos Humanos: la Declaración de la Unesco. Bioética. Brasília, v. 7, n. 2, p. 165-178, 1999.

BITTAR, Carlos Alberto. Os direitos da personalidade. 5. ed. rev. atual. aum. por Eduardo C. B. Bittar. Rio de Janeiro: Forense Universitária, 2001.

BRUNET, Karina Schuch. Engenharia genética: implicações éticas e jurídicas. Revista Jurídica, São Paulo, n. 274, p. 44-56, 2000.

CARVALHO, Ana Paula Gambogi. O consumidor e o direito à autodeterminação informacional. Revista de Direito do Consumidor, São Paulo, n. 46, p. 77-118, abr. 2003.

CORTIANO JUNIOR, Eroulths. Alguns apontamentos sobre os chamados direitos da personalidade. In: FACHIN, Luiz Edson [coord.]. Repensando fundamentos do direito civil brasileiro. Rio de Janeiro: Renovar, 1998. p. 31-56.

- Direitos da personalidade: direito à vida, ao próprio corpo e ao cadáver. Curitiba, 1993. Dissertação de Mestrado - Departamento de Direito, Universidade Federal do Paraná.

COSTA JUNIOR, Paulo José da. O direito de estar só: tutela penal da intimidade. São Paulo: RT, 1995.

DANTAS, San Tiago. Programa de direito civil: aulas proferidas na Faculdade Nacional de Direito. Rio de Janeiro: Rio, 1942-1945.

DONEDA, Danilo. Os direitos da personalidade no novo Código Civil. In: TEPEDINO, Gustavo [coord.]. A parte geral do novo Código Civil: estudos na perspectiva civil-constitucional. Rio de Janeiro: Renovar, 2002. p. 35-58.

EFING, Antonio Carlos. Bancos de dados e cadastros de consumidores. São Paulo: RT, 2002 (Biblioteca de direito do consumidor, v. 18).

FARIAS, Edilsom Pereira de. Colisão de direitos. A honra, a intimidade, a vida privada e a imagem versus a liberdade de expressão e informação. Porto Alegre: Fabris, 1996. 
FERREIRA, Jussara Suzi Assis Borges Nasser. Bioética e biodireito. Disponível em http://www.uel.br/cesa/dir/pos/publicacoes/pubjussaraf.html. Acesso em: 20 jan. 2005.

FRANÇA, Rubens Limongi. Direitos privados da personalidade. Revista dos Tribunais, São Paulo, v. 370, p. 7-16, ago. 1966.

GARRAFA, Volnei; COSTA, Sérgio Ibiapina Ferreira; OSELKA, Gabriel. A bioética no Século XXI. Bioética, Brasília, v. 7, n. 2, p. 207-212, 1999.

GOMES, Orlando. Direitos de personalidade. Revista Forense, Rio de Janeiro, v. 216, p. 5-10, out./dez. 1966.

GOMES, Orlando. Introdução ao direito civil. 15. ed. atual. e notas de Humberto Theodoro Junior. Rio de Janeiro: Forense, 2000.

MEIRELLES, Jussara Maria Leal. Bioética e biodireito. In: BARBOZA, Heloíza Helena; BARRETO, Vicente de Paulo [orgs.]. Temas de biodireito e bioética. Rio de Janeiro: Renovar, 2001. p. 85-97.

- O ser e o ter na codificação civil brasileira: do sujeito virtual à clausura patrimonial. In: FACHIN, Luiz Edson [coord.]. Repensando fundamentos do direito civil brasileiro. Rio de Janeiro: Renovar, 1998. p. 87-114.

MYSCZUK, Ana Paula. Limites jurídicos à manipulação do genoma humano: a Declaração Universal do Genoma Humano e dos Direitos Humanos, a Constituição Federal de 1988 e atual Legislação Brasileira de Biossegurança. Curitiba, 2002. Dissertação de Mestrado - Departamento de Direito, Pontifícia Universidade Católica do Paraná.

OLIVEIRA, José Lamartine Corrêa de; MUNIZ, Francisco José Ferreira. O estado de direito e os direitos da personalidade. Revista da Faculdade de Direito da Universidade Federal do Paraná, Curitiba, v. 19, p. 223-241, 1978-1980.

PASSOS-BUENO, Maria Rita. O projeto genoma humano. Bioética, Brasília, v. 5, n. 2, p. 145-155, 1997.

PEREIRA, Caio Mário da Silva. Instituições de direito civil: introdução ao direito civil; teoria geral do direito civil. 19. ed. rev. atual. Rio de Janeiro: Forense, 2000.

PESSINI, Léo; BARCHIFONTAINE, Christian de Paul de. Problemas atuais de bioética. 4. ed. rev. ampl. São Paulo: Loyola, 1997.

SALGADO, Joaquim Carlos. A idéia de justiça em Kant: seu fundamento na liberdade e na igualdade. 2. ed. Belo Horizonte: UFMG, 1995.

SGRECCIA, Elio. Manual de bioética. São Paulo: Loyola, 1996. v. 1: Fundamentos e ética biomédica. 
SIDON, J. M. Othon. PERSONALIDADE II. In: ENCICLOPÉDIA Saraiva de Direito. São Paulo: Saraiva, 1914-1981. v. 58, p. 214-226.

SZANIAWSKI, Elimar. Direitos da personalidade na antiga Roma. Revista de Direito Civil, Imobiliário, Agrário e Empresarial, São Paulo, v. 43, p. 28-41, jan./fev.1988.

. Direitos de personalidade e sua tutela. São Paulo: RT, 1993.

TEPEDINO, Gustavo. Temas de direito civil. Rio de Janeiro: Renovar, 2001.

XAVIER, Elton Dias. A bioética e o conceito de pessoa: a re-significação jurídica do ser enquanto pessoa. Bioética, v. 8, n. 2, 2000. Disponível em http://www.portalmedico.org.br/revista/bio2v8/simpo2.htm. Acesso em: 15 de jan. 2005. 